\title{
Fetal Central Nervous System and Thymic Alterations Following Cyclophosphamide Treatment of Pregnant Mice
}

\author{
Alteraciones del Sistema Nervioso Central Fetal y Tímicas Posterior al Tratamiento con \\ Ciclofosfamida en Ratas Preñadas
}

"Prakash; ** Gajendra Singh \& ${ }^{* * *}$ Sukh Mahendra Singh

\begin{abstract}
PRAKASH; SINGH, G. \& SINGH, S. M. Fetal central nervous system and thymic alterations following cyclophosphamide treatment of pregnant mice. Int. J. Morphol., 25(4):775-787, 2007.

SUMMARY: The present study assessed central nervous system (CNS) and immune system changes in murine fetuses after cyclophosphamide (CP) exposure during intrauterine life. A single CP dose of 0,10 , or $20 \mathrm{mg} / \mathrm{kg}$ body weight was administered by intraperitoneal injection to pregnant mice (20/group) on day 11 of gestation (GD 11) and fetuses were evaluated on day 19 of gestation (GD 19). Fetuses were examined for external changes, and then the brains and thymuses were removed for further evaluations of histological changes, protein content, apoptotic cell count, DNA fragmentation, and in vitro cell proliferation using 1 fetus/litter for each assessment. Brains and thymuses from CP-exposed fetuses were smaller in size and distorted in overall shape compared to those from the control group. Estimated mean protein content $(\mathrm{mg} / \mathrm{mL})$ of brains was decreased in the CP-exposed groups. In both brain cells and thymocytes there was an increase in mean apoptotic cell counts and in mean percent DNA fragmentation in the exposed groups. The in vitro cell proliferation assays conducted with cells from exposed fetuses exhibited a mean decrease in the number of both brain cells and thymocytes generated. These findings indicate that maternal CP treatment on GD 11 in mice results in marked fetal toxicity characterized by reduced live litter size, fetal body weights as well as brain and thymic weights and malformations which are accompanied by changes in brain protein content, brain and thymic apoptosis, DNA fragmentation and in vitro cell proliferation at term.
\end{abstract}

KEY WORDS: Cyclophosphamide; Brain; Thymus; Mice; Teratology.

\section{INTRODUCTION}

This study is focused to establish neurological and immunological embryopathic effects from gross to biochemical levels induced by cycloposphamide (CP) administration during pregnancy in mice so that it can be applied clinically for more effective and safe therapeutic use during the gestational period in human beings. No complete study incorporating all the aforementioned details have been reported till date in literature.

$\mathrm{CP}$ is the most widely used alkylating (antineoplastic) agent. $\mathrm{CP}$ has potent immunosuppressive properties and is used clinically in a number of autoimmune disorders like Wegeners granulomatosis, rheumatoid arthritis, nephritic syndrome, systemic lupus erythmatosus and has also been used to prevent organ rejection after transplantation (Bruton et al., 2006). It is indicated in myeloproliferative and lymphoproliferative disorders including various types of leukemia and lymphomas. It is also used clinically in management of neuroblastoma, retinoblastoma, adenocarcinoma of the ovary, carcinoma of the breast, and neoplasms of the lung. Long term therapies are required in majority of the aforementioned conditions. $\mathrm{CP}$ is classified as a pregnancy risk factor D drug. Its use in pregnancy is justified only when potential maternal benefits outweigh the possible risk including the birth defects. Some pregnant women who have to use immunosuppressive drugs for the treatment of diseases like leukemia (Pizzuto et al., 1980), non-Hodgkin's lymphoma (Falkson et al., 1980), systemic lupus erythmatosus (Kirshon et al., 1988) do not always agree to interrupt their pregnancy even when knowing about the risks of such treatment (De Lucia et al., 2005). Since all the indications do not have safer alternatives during pregnancy,

* Department of Anatomy, Kasturba Medical College, Mangalore, Karnataka, India.

** Department of Anatomy, I. M. S., B. H. U., Varanasi, U. P., India.

${ }^{* * *}$ School of Bio-technology, B. H. U., Varanasi, U. P., India. 
situations may arise when $\mathrm{CP}$ has to be used, even in first trimester of pregnancy in view of maternal safety on cost of the fetal outcomes.

A wide spectrum of the teratogenic effects of $\mathrm{CP}$ have been reported involving multiple tissues and organ systems of animals, but more population based studies may still be essential to conclusively demonstrate teratogenicity of $\mathrm{CP}$ in humans (Enns et al., 1999; Kirshon et al.; Pillans et al., 1989; Pillans et al., 1988; Pizzuto et al.; Reddy et al., 2003; Singh et al., 1983; Singh et al., 1990; Torchinsky et al., 2002; Wendler, 1980; Zemlickis et al., 1993). However, a number of studies demonstrate that $\mathrm{CP}$ is a human teratogen due to its effects such as intrauterine growth retardation and multiple anomalies including microbrachycephaly, coronal craniosynostosis, hypotelorism, shallow orbits, proptosis, blepharophimosis, abnormal and small ears, unilateral preauricular pit, broad, flat nasal bridge, microstomia, higharched palate, micrognathia, cranial anomalies, preaxial upper limb and post-axial lower limb defects consisting of hypoplastic thumbs, and oligodactyly like bilateral absence of $4^{\text {th }}$ and $5^{\text {th }}$ toes (Enns et al., 1999). Zemlickis et al. reported a case of 29-year old pregnant woman diagnosed with acute lymphocytic leukemia maintained remission with daily $\mathrm{CP}$ and intermittent prednisone treatment, where two delivered twin babies manifested different fetal outcomes. The male twin had multiple congenital anomalies including esophageal atresia, Madelung deformity, abnormal inferior vena cava, abnormal renal collecting system, cryptorchidism with rudimental left testicle, and radial anomaly with abnormal thumb; and was diagnosed with papillary thyroid cancer at 11 years of age and stage III neuroblastoma at 14 years of age. On the contrary, the female twin was unaffected and has exhibited normal development to date of report (Zemlickis et al.). Bergstrom et. al (1998) reported cases of two 15 year old girls with "high risk" Acute Lymphoblastic Leukemia, who became pregnant while receiving maintenance therapy. In one case, the patient experienced a spontaneous abortion at approximately 5 to 6 weeks gestation, while the second patient delivered an apparently normal baby girl (Bergstrom et al.). No congenital anomalies were observed in one case series among 21 children born to women treated (half of them in first trimester) with CP in cancer chemotherapeutic regimens during pregnancy (Aviles et al., 1991).

$\mathrm{CP}$ is widely distributed in several tissues in both animals and humans (Bruton et al.). The drug can cross placenta, found in breast milk and ascitic (excess accumulation of peritoneal) fluid. This may be particularly important in relation to the fact that CNS abnormalities are the foremost among the malformations induced by the drug. Investigations provide evidences implicating CP-induced cell death as a common event in the pathogenesis associated with tissues destined to be malformed (Mazur-Kolecka et al., 1996). Although the importance of this cell death is recognized, little information is available concerning the biochemistry of teratogen-induced cell death. Apoptosis is a potential mechanism for teratogenicity and altering apoptosis is a target action of CP (Chen et al., 1994; De Lucia et al.; Mirkes et al 1998). CP actions on programmed cell death (at molecular level) are the most important outcomes involved in its teratogenic manifestations out of its various cytotoxic effects in the embryo. When apoptosis is disturbed by inhibited or inadequate induction, malformations certainly occur (Bursch et al., 1992; De Lucia et al.; Torchinsky et al., 1999). Brill et al. (1999) summarized data on the mechanisms of programmed cell death and concentrated on apoptosis involved in normal or disturbed gametogenesis and in normal and abnormal embryonic development. Immunosuppressive property of $\mathrm{CP}$ has tremendous impact during pregnancy which manifest as various fetal outcomes. Holladay et al. (2002) discussed mechanisms by which maternal immune stimulation in mice decreases fetal malformations caused by teratogens and suggested the possibility that immunoregulatory cytokines of maternal origin may be the effector molecules in this phenomenon. Savion et al. (2003) suggested a possible role for maternal immunopotentiation in protecting the embryo from teratogenic insults, possibly through regulation of the $\mathrm{CP}$ induced apoptosis process and the expression of $\mathrm{p} 53$ and bcl2. Immunopotentiation with rat splenocytes or GM-CSF was shown to partially normalize the teratogenic effect of $\mathrm{CP}$, and was also found to partially decrease the CP-induced apoptotic process and exhibited a tendency to normalize the expression of p53 and bcl-2 in embryonic head and liver (Savion et al.). Ivnitsky et al. (2001) concluded that maternal immune stimulation by intrauterine injection with rat splenocytes 21 $\mathrm{h}$ before mating blocked the elevated TGF $\mathrm{b} 2$ mRNA and protein levels in CP-treated fetal tissues. Teratogen-induced cell death is also selective, cells within some tissues die when exposed to $\mathrm{CP}$ while other cells are relatively resistant to the CP-induced cell death (Mirkes et al.).

The spectrum of teratogenic effects produced by CP in various species shows a striking similarity (Singh et al., 19983; Singh et al., 1990; Torchinsky et al., 2002). CP is known to produce a full spectrum of congenital malformations with CNS defects on the top of the list (Pillans et al., 1989; Pillans et al., 1988; Singh et al., 1990). CP exposure leads to multiple central nervous systems (CNS) anomalies, the mode of neuronal damage need to be established and we have chosen murine system for our study. We further intend to investigate the teratological insult caused by CP on murine fetal thymuses. Some preliminary studies have indicated the involvement of nervous system in CP induced immune disorders (MazurKolecka et al.). 
The selected doses were based on common schedules of human maintenance therapy: (1) 1 to $5 \mathrm{mg} / \mathrm{kg}$ orally, daily; (2) 10 to $15 \mathrm{mg} / \mathrm{kg}$ i.v., every 7 to 10 days; 3 to $5 \mathrm{mg} / \mathrm{kg}$ i.v., twice weekly. The use of one single high dose was based on report by Lopes et al. (1987), who showed it to have longerlasting teratogenic effect. The selection of specific time of treatment (GD11) was based on report by Torchinsky et al. (2002), who administered single dose of $15 \mathrm{mg} / \mathrm{kg}$ body weight CP on GD12, which corresponds to GD11 of our study as he considered sperm positive day as day one against our day zero of pregnancy.

\section{MATERIAL AND METHOD}

Approval of Animal Ethical committee of the Institute was obtained prior to the present work.

Sexually mature swiss white female and male mice weighing 16-36 g obtained from Central Animal House of the Institute were used in this study.

CP manufactured by Khandewal laboratories Mumbai, India with trade name Endoxan-Asta was used in the experiment.

Reagents and culture medium: Hank's Balanced Salt Solution (HBSS), tissue culture medium RPMI 1640, and most of the other reagents were purchased from Sigma Chemical Company (U.S.A.). Culture medium was supplemented with $25 \mathrm{mg} / \mathrm{ml}$ Gentamycin, $100 \mathrm{mg} / \mathrm{ml}$ Streptomycin, 100 I.U. Penicillin and 10\% heat inactivated foetal calf serum (Hyclone, U.S.A.).

Female mice during their proestrous phase of estrous cycle were caged overnight with the males of the same stock (female: male $=1: 1$ ). The vaginal smear was examined next morning at 8.00 a.m. Presence of spermatozoa in the smear or vaginal plug was taken as day "zero" of pregnancy. A total of 60 pregnant female mice were euthanized in the present study. They were divided into control group (20) and treated group (40). The treated group were divided further into two groups of 20 animals each, which received intraperitoneally CP on day 11 of gestation (GD11) in dose of 10 or $20 \mathrm{mg} / \mathrm{kg}$ body weight in $0.5 \mathrm{ml}$ saline per $20 \mathrm{~g}$ body weight. Controls received $0.5 \mathrm{ml}$ saline per $20 \mathrm{~g}$ body weight on GD11. The animals were observed for maternal weight gain during the gestational period.

The pregnant mice were killed with overdose of ether anesthesia on day 19 of gestation (GD19) i.e. one day prior to full term. The uterine horns were exteriorized after opening the abdomen by midline incision and the number of implantations and fetal resorptions were recorded. The fetuses were removed from the uterus and were dried by wiping on a blotting paper. Fetuses were examined for gross malformations and size (crown-rump length) and body weight were recorded. Brains were dissected out from cranial cavities of fetuses. Further thymuses were also dissected out. Bouin's solution was used for fixation and they were prepared for light microscopic study by paraffin section. Brains and thymuses were serially cut at $8 \mu \mathrm{m}$ thickness in coronal and transverse plane and were stained with haematoxylin and eosin. A total of 120 fetuses (40 per group and 2 per litter) were selected randomly and examined histologically and 1 section per brain (total $40 \times 3=120$, slides) was examined under microscope. Photomicrographs of histological findings were obtained at different magnification.

Two fetuses from each of 60 litters (divided into three groups) was selected randomly and used for each of the assay mentioned below.

Quantitative estimation of proteins: Protein contents in different samples of cell lysates, prepared by repeated freeze thaw were determined by standard Folin's method. $200 \mu \mathrm{l}$ of reagent [alkaline copper solution: $25 \mathrm{ml}$ of reagent $\mathrm{A}\left(2 \% \mathrm{Na}_{2} \mathrm{CO}_{3}\right.$ in $\left.0.1 \mathrm{~N} \mathrm{NaOH}\right)+0.5 \mathrm{ml}$ of reagent $\mathrm{B}(0.5 \%$ of $\mathrm{CuSO}_{4} .5 \mathrm{H}_{2} \mathrm{O}$ in $1 \%$ sodium potassium tartarate)] was mixed with $40 \mu$ l of cell lysate followed by incubation at room temperature for $10 \mathrm{~min}$. $20 \mu \mathrm{l}$ of Folin-Ciocalteu's Phenol reagent (freshly diluted with water in 1:1 ratio was added to the above reaction mixture and allowed to stand at room temperature for $30 \mathrm{~min}$. Absorbance was measured on an Elisa plate reader (lab: system, Finland) at $620 \mathrm{~nm}$ with water taken as blank.

Morphological evaluation of apoptotic cells: Thymocytes smeared on a slide were air dried, fixed in methanol, and stained with Wright staining solution, mounted in glycerine and analyzed under light microscope at $450 \mathrm{x}$ magnifications. The percentage of apoptotic cells were determined by counting more than 300 cells in at least three separate fields.

Percent DNA fragmentation was quantified following a method described by Sellins \& Cohen (1987) with slight modifications. Thymuses and brains extirpated from mice, killed by cervical dislocation, were weighed on a chilled watch glass, diced on ice, and passed through a stainless steel screen using a syringe plunger. These cells, after washing with $0.15 \mathrm{M}$ phosphate buffered saline (PBS) $\mathrm{pH}$ 7.2 by centrifugation at $200 \mathrm{~g}$, for 10 minutes, at $4^{\circ} \mathrm{C}$ were used for testing cell number. Brain cells or thymocytes $(5 \mathrm{x}$ 105 cells $/ \mathrm{ml}$ ) were suspended in $0.5 \mathrm{ml}$ of lysis buffer (Tris 
-EDTA buffer, $\mathrm{pH} 7.4$ containing $0.2 \%$ Triton $\mathrm{x} 100$ ) and were centrifuged for $15 \mathrm{~min}$ at $13000 \mathrm{x} \mathrm{g}$ at $4^{\circ} \mathrm{C}$ in a microfuge tube (labeled as B). Supernatant was transferred to another tube (labeled as T). $0.5 \mathrm{ml}$ of $25 \%$ trichroloacetic acid was added to $\mathrm{T}$ and $\mathrm{B}$ tubes followed by vigorous vortexing.

Tubes were kept overnight at $4^{\circ} \mathrm{C}$ for precipitation. Supernatant was discarded after centrifugation at $13000 \mathrm{xg}$ for $10 \mathrm{~min}$ and then DNA in each pellet was hydrolyzed in $80 \mu \mathrm{l}$ of $5 \%$ trichloroacetic acid by heating on a water bath at $90^{\circ} \mathrm{C}$ for $15 \mathrm{~min} .160 \mu \mathrm{l}$ of freshly prepared diphenylamine (150mg diphenylamine in $10 \mathrm{ml}$ glacial acetic, $150 \mu \mathrm{l}$ concentrated $\mathrm{H}_{2} \mathrm{SO}_{4}$ and $50 \mu \mathrm{l}$ of acetaldehyde solution) was added and the tubes were allowed to stand overnight at room temperature to develop colour. $100 \mu$ l of this colored solution was transferred to a 96 well flat bottom ELISA plate and absorbance was measured at $600 \mathrm{~nm}$ on an ELISA plate (Tarsons) reader (Lab systems, Finland).Percent fragmented DNA was calculated using the formula.

$$
\% \text { Fragmented } \mathrm{DNA}=(\mathrm{T} / \mathrm{T}+\mathrm{B}) \times 100
$$

Where $\mathrm{T}=$ absorbance of fragmented $\mathrm{DNA}$ and $\mathrm{T}+\mathrm{B}=$ absorbance of total DNA.

Cell proliferation (number) assay of brain cells or thymocytes: The tissues were mechanically dissociated using a standard glass homogenizer. The dissociated cells ( 1 x 106) were seeded in medium supplemented with $5 \%$ fetal calf serum in a 96 well tissue culture plate and incubated at $37^{\circ} \mathrm{C}$ in a humidified atmosphere of $5 \% \mathrm{CO}_{2}$ in air for $72 \mathrm{~h}$ in a $\mathrm{CO}_{2}$ incubator (Sheldon, USA). MTT (Tetrazolium) assay was carried out to estimate cell number following a method described by Singh et al. (2003). MTT [3-(4, 5dimethylthiazol-2yl)-2,5-diphenyl tetrazolium bromide] was dissolved in PBS at a concentration of $5 \mathrm{mg} / \mathrm{ml}$. $50 \mu \mathrm{l}$ of MTT solution was added to each well of culture plate containing $200 \mu \mathrm{l}$ medium and incubated at $37^{\circ} \mathrm{C}$ for $4 \mathrm{~h}$. Medium was then removed carefully without disturbing the dark blue formazan crystals. $50 \mu \mathrm{l}$ of DMSO was added tom each well and mixed thoroughly to dissolve the crystals of formazan. The plates were then read on a microplate reader (Lab. System, Finland) at a wavelength of $540 \mathrm{~nm}$. Readings are presented as OD at $540 \mathrm{~nm}$.

Statistical analysis. Litter was the unit of analysis for statistical procedures and was selected randomly (Holson \& Pierce 1992). Different form of data was tested for statistical significance by using one way analysis of variance (ANOVA) test with the help of statistical software programs (GraphPad Prism). The results have been expressed in percentage and mean + SD. Any value of $\mathrm{p}<0.05$ at $95 \%$ confidence interval was regarded as significant.

\section{RESULTS}

$\mathrm{CP}$ administration resulted in significant reduction in maternal weight gain during gestation along with significant increase in fetal resorption recorded out of total number of implantations in both the treated groups in a dose dependent manner (Table I). To assess the overall toxicity profile two fetuses from each of 60 litters (divided into three groups) was used. Gross examination of the fetuses exhibited significant reduction in mean live litter size along with growth retardation and reduction in body weight (Fig.1, Tables I and II) along with various external malformations, of which important were stunting in size, open eyes, rudimentary limbs, malrotated limbs, short neck, polydactyly, kinking of tail, and hemorrhage on body surface (Fig.1 and Table III). The observations of the present study are focused around profound and persistent changes in the fetal brain and thymus. Further gross examination of brains reflected reduction in its size and distortion in shape along with a significant reduction in weight (Table II, Fig. 2A, and Fig. 2B). CP treatment also resulted in a significant reduction in the weight of fetal thymuses and loss of its lobular structure (Table II).

Most important histological finding in brain was incomplete development and failure of canalization of cerebral aqueduct manifesting as hydrocephalus and cavity formation (Fig. 3 and Table III). Examination of ventricular cavities showed hemorrhages at several places in the choroids plexus (Fig. 4).

Results of biochemical evaluations were more valid and convincing. A dose dependent decline in protein content of brain tissue was observed following CP treatment to pregnant mice as compared to that of brain of fetuses obtained from control(Fig. 2C, p $<0.05$, and Table II).

Biochemical evaluations and in vitro study in cell culture system confirmed similar response in brain tissue. Percent DNA fragmentation in the DNA from brain cells of CP treated litters showed a dose dependent increase as compared to that of control group (Fig.7A, $<<0.05$ ). On the contrary, cell proliferation (number) assay showed concomitant decrease in brain cells. CP administration resulted in a dose dependent massive reduction in brain cells number as compared to the number of brain cells from control litters (Fig.7B, p<0.05). The brain cells number was reduced to one third, in the $20 \mathrm{mg} / \mathrm{kg}$ body weight $\mathrm{CP}$ treated group (Fig.7B, p<0.05).

Histological examination of thymic tissues at different magnifications revealed increased number of apoptotic thymocytes in CP treated group as compared the control 
Table I. Effects of intrauterine exposure to cyclophosphamide on pregnant mice and litters.

\begin{tabular}{lccccc}
\hline Groups & $\begin{array}{c}\text { Number of } \\
\text { pregnant mice }\end{array}$ & $\begin{array}{c}\text { Maternal weight gain } \\
\text { during gestation in }\end{array}$ & $\begin{array}{c}\text { Number } \\
\text { of }\end{array}$ & $\begin{array}{c}\text { Number and } \\
\text { \% of fetal }\end{array}$ & $\begin{array}{c}\text { Crown-rump length } \\
\text { of live fetuses in man }\end{array}$ \\
& treated & Mean \pm SD) & implantations & resorption & (Mean \pm SD) \\
\hline Control (normal saline) & 20 & $19.9 \pm 1.87$ & 162 & $2(1.24)$ & $25.8 \pm 2.05$ \\
Treated $(10 \mathrm{mg} / \mathrm{kg}$ body weight $\mathrm{CP})$ & 20 & $14.6 \pm 1.46^{*}$ & 160 & $34(21.25)$ & $19.4 \pm 1.76^{*}$ \\
Treated $(20 \mathrm{mg} / \mathrm{kg}$ body weight $\mathrm{CP})$ & 20 & $8.8 \pm 1.18^{*}$ & 155 & $56(36.13)$ & $14.1 \pm 1.42^{*}$ \\
\hline
\end{tabular}

$*$ P value was $<0.05$ at $95 \%$ confidence interval.


Fig. 1. Photographs of fetuses collected on day 19 of gestation. A. The left side two fetuses C-1 and C2 were collected from control dams and the other four fetuses on the right side were collected from dams exposed to CP with 10 (T1\&T2) and 20 (T3\&T4) $\mathrm{mg} / \mathrm{kg}$ dose on day 11 of gestation. The fetuses of treated dams were smaller in size. Stunting in size was proportionate to the dose of CP.; B. Fetuses of CP treated dams (20 mg on day 11) showing different types of malformations i.e. $\mathrm{T} 1=$ Stunting in size, open eyes (arrow), malrotated limbs (star). T2 $=$ Stunting in size, short neck $($ arrow $)$. T3 $=$ Stunting in size, polydactyly (arrow) with elephantiasis (large size of right hind limb). T4 = Severe stunting in size, grossly malformed (star), rudimentary limbs. T5 $=$ Stunting in size, hemorrhage on left side of body surface (arrow). T6 = Stunting in size, malrotated left hind limb (arrow). $\mathrm{T} 7=$ Stunting in size, short neck (arrow), kinking of tail. T8 = Stunting in size, hemorrhage on left side of body surface (arrow). group (Fig. 8). In order to check further, the mode of cell death in thymocytes obtained from fetuses of CP treated mice; morphological analysis of such cells was performed. $\mathrm{CP}$ administration resulted in an increase in the number of apoptotic thymocytes in a dose dependent manner (Fig. 5A, $\mathrm{p}<0.05)$. This observation was later confirmed by quantification of percent specific DNA fragmentation. Percent DNA fragmentation in the DNA from thymocytes of CP treated litters showed a dose dependent increase as compared to that of control group (Fig. 5B, p<0.05).

Effect of $\mathrm{CP}$ administration on cell proliferation (number) assay of thymocytes obtained from fetuses of CP treated or control litters were assayed by standard MTT method as described in materials and methods. CP administration resulted in a dose dependent decline in thymocyte number as compared to the thymocytes number from control litters (Fig. 6, p<0.05). 

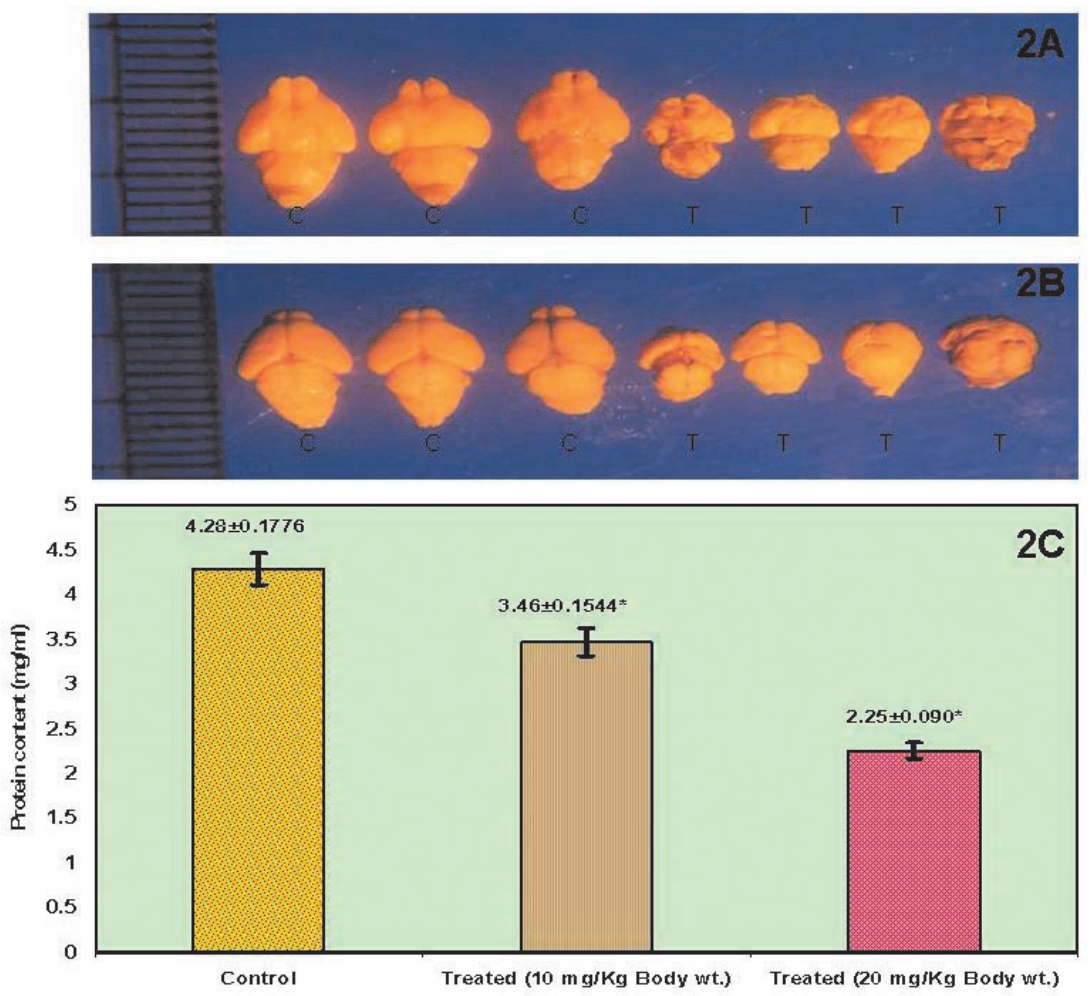

Fig. 2. Photographs of brains dissected out from fetuses collected on day 19 of gestation. Fetuses collected from treated dams were given $\mathrm{CP}$ on day 11 in the dose of 10 and 20 $\mathrm{mg}$. A. Ventral view of brains of fetuses collected from control (C) and treated (T) dams. The brains of fetuses collected from treated dams are smaller in size and distorted in shape as compared to brains collected from control group; B. Dorsal view of brains of fetuses collected from control $(\mathrm{C})$ and treated (T) dams. The brains of fetuses collected from treated dams are smaller in size and distorted in shape as compared to brains collected from control group; C. Effect of in vivo administration of $\mathrm{CP}$ to pregnant mice on total protein content of fetal brain. Brain tissue obtained from normal or CP treated litters was lysed by freeze thaw technique and protein content in the lysate was measured by standard Follin's method. Values are mean \pm SD of independent experiments done in triplicate. $* \mathrm{P}$ value $<0.05$ at $95 \%$ confidence interval.
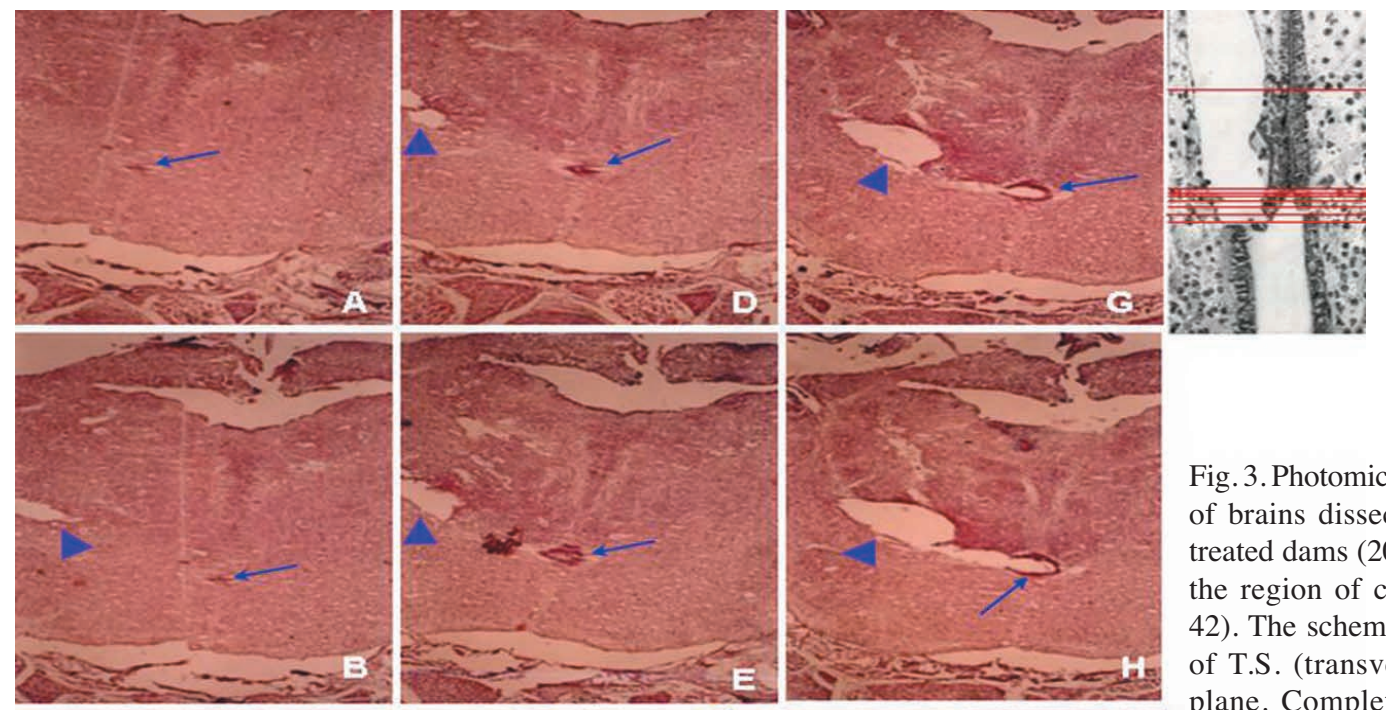

Fig. 3. Photomicrographs of serial sections of brains dissected out from fetuses of treated dams (20 mg CP on day 11) from the region of cerebral aqueduct. (H\&E 42). The schematic drawing shows level of T.S. (transverse section) in coronal plane. Complete agenesis of aqueduct (arrow) - A, B \& C. The lumen has just
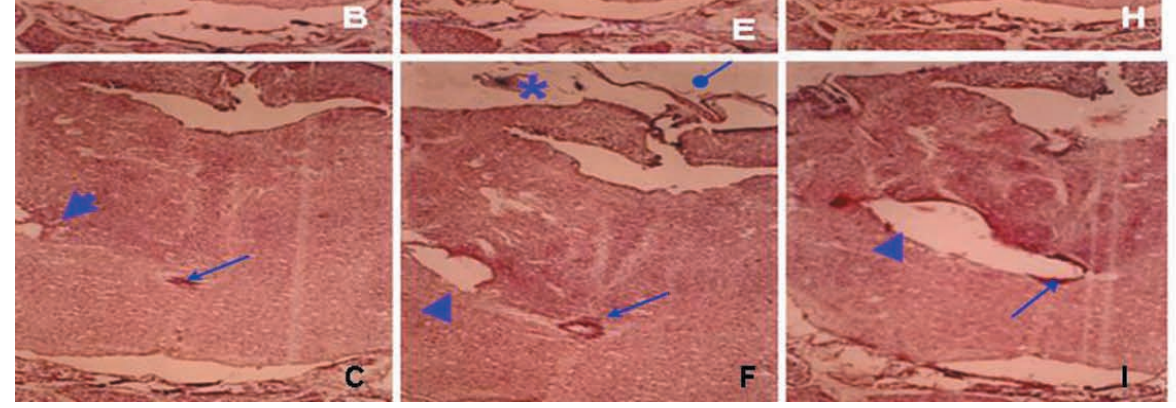
appeared in D (arrow) which gradually increased in width in $\mathrm{E}, \mathrm{F}, \mathrm{G}, \mathrm{H}$. I. Photomicrographs $\mathrm{G}, \mathrm{H}$, I show disruption in the continuity of the ependyma (arrow) surrounding the cerebral aqueduct. Thus, forcing the CSF laterally through the brain substance and resulting in a cavity parallel to the cerebral aqueduct (schematic

drawing). Photomicrograph of the lowermost section (I) shows a continuous big cavity, including the cerebral aqueduct. Lateral ventricle shows communication in mid saggital plane with the subarachnoid space causing external hydrocephalus (star). Gross specimen showed very thin calveria which in section F (oval arrow head) is seen as thin skin with folding. 

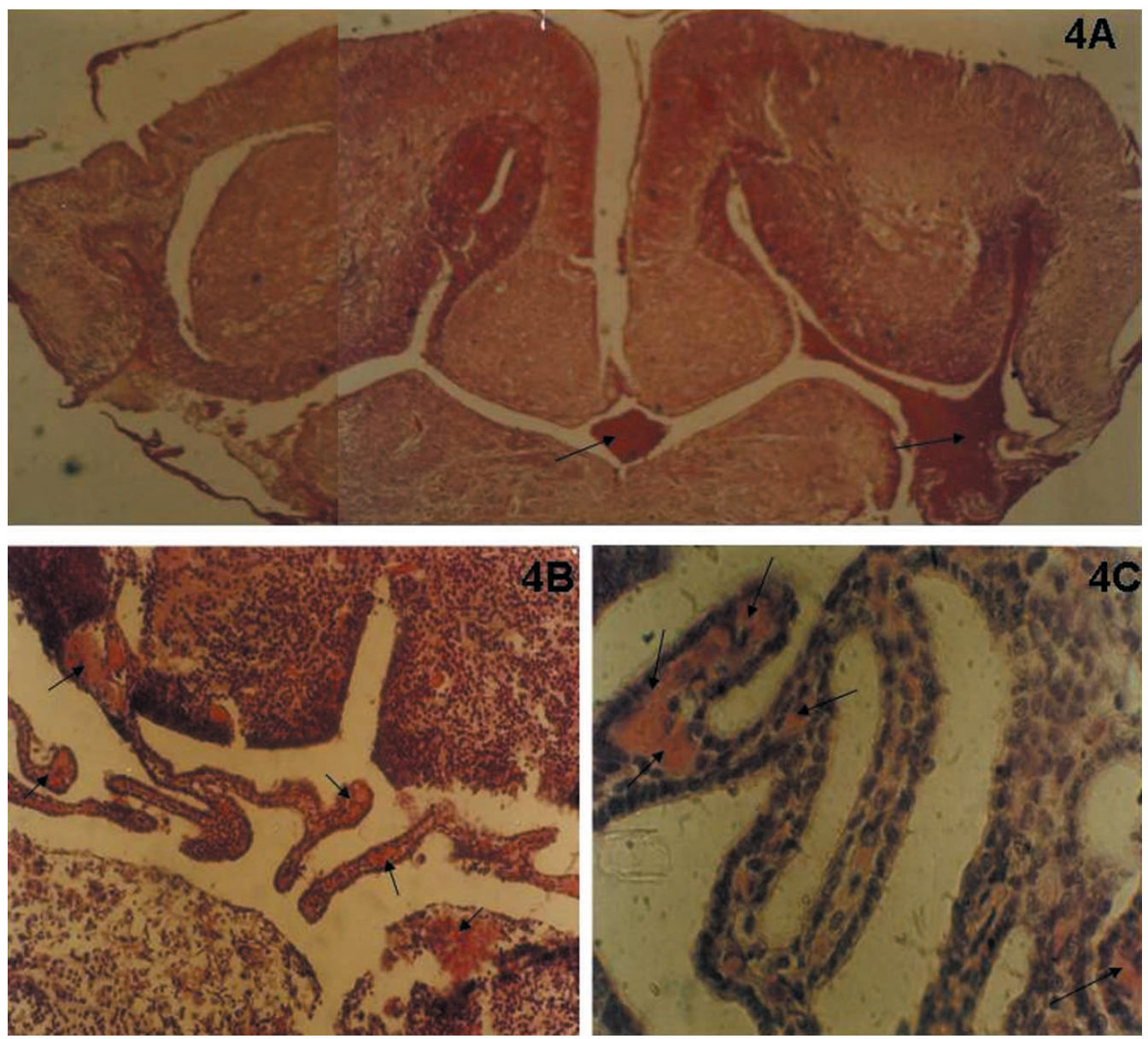

Fig. 4. Photomicrographs of brains dissected out from fetuses of treated dams (20 mg CP on day 11) which were collected on day 19 of gestation. Photomicrographs of serial sections were from the region of cerebral aqueduct. (H\&E x 42). A. Histological section of brain in coronal plane showing hemorrhage in the ventricular cavities (arrows) (H\&E x 42); B. Histological section of brain of treated fetus in coronal plane at high magnification showing hypertrophy and haemorrhage in choroid plexus (arrows) (H\&E x 168). C. Histological section of brain of treated fetus in coronal plane at very high magnification showing choroid plexus and ependymal cells. Haemorrhage in the hypertrophied choroid plexus is evident (arrows) (H\&E x 672).
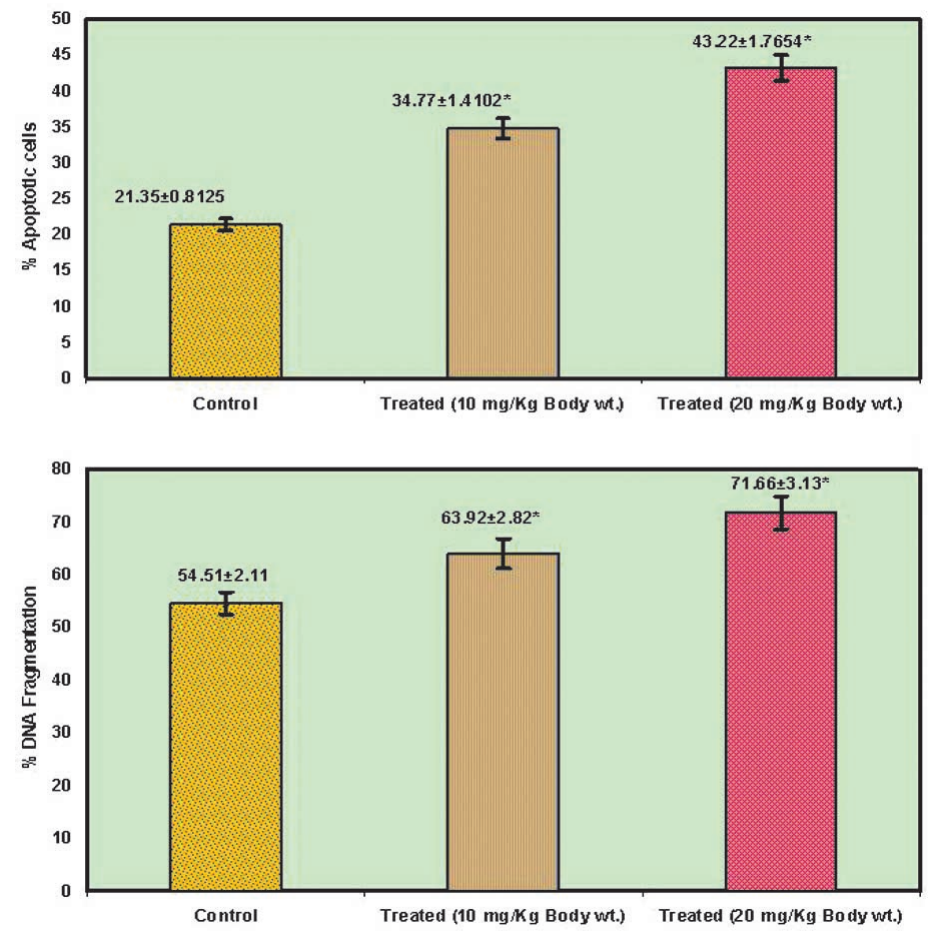

Fig. 5A. Effect of in-vivo administration of $\mathrm{CP}$ to pregnant female mice: on the induction of apoptosis in fetal thymocytes. Percentage of apoptotic cells was determined on the basis of morphological features in Wright stained preparation of single cell suspension of thymocytes. Values are mean $\pm \mathrm{SD}$ of 3 independent experiments done in triplicate. $* \mathrm{P}$ value $<0.05$ at $95 \%$ confidence interval.

Fig. 5B. Effect of in-vivo administration of $\mathrm{CP}$ to pregnant female mice on $\%$ DNA fragmentation of thymocytes of the fetuses. Percent fragmentation of DNA obtained from thymocytes of control and $\mathrm{CP}$ treated groups was quantified as described in materials and methods. Values are mean \pm SD from 3 independent experiments done in triplicate. ${ }^{*} \mathrm{P}$ value $<0.05$ at $95 \%$ confidence interval. 

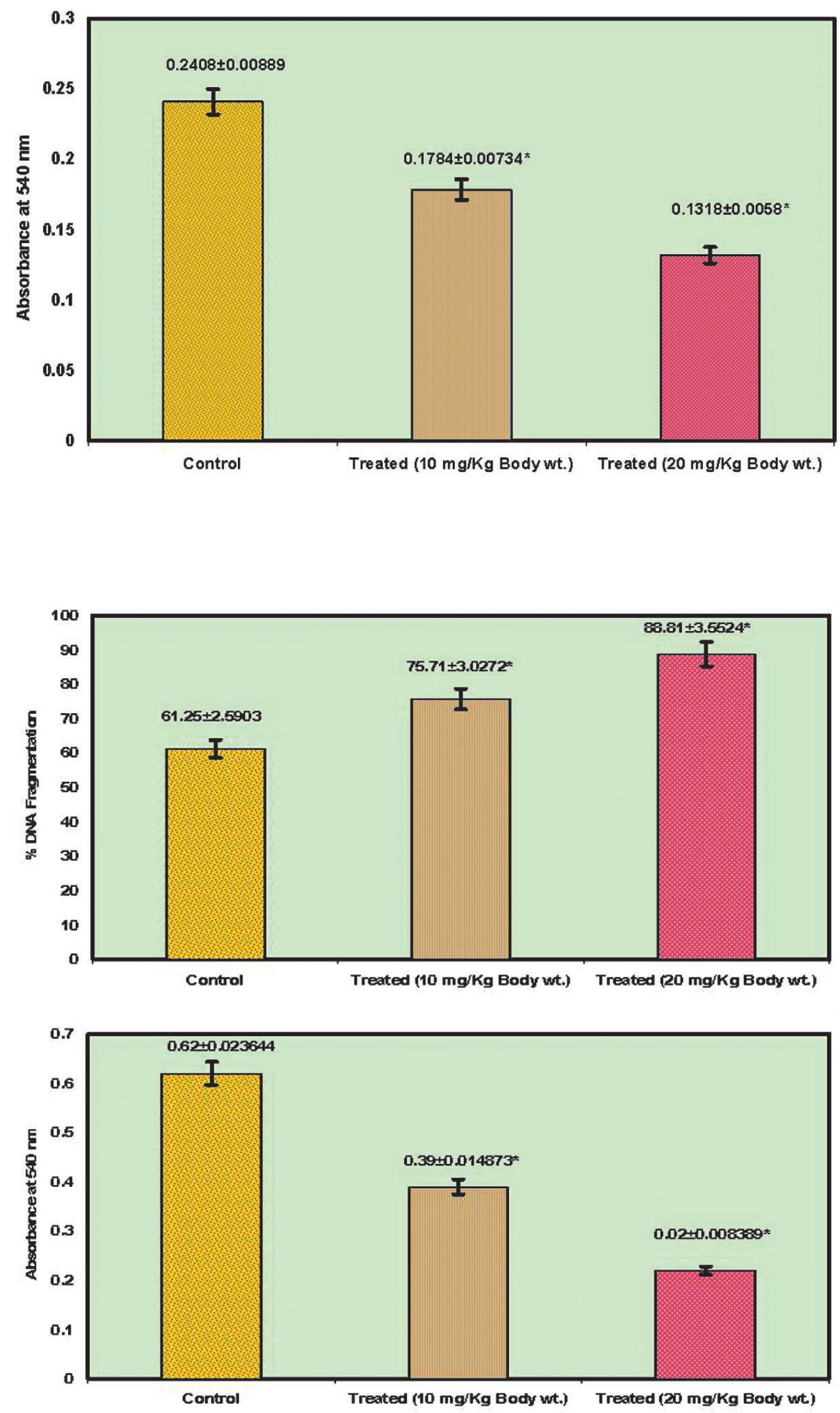

Fig. 6. Effect of in-vivo administration of $\mathrm{CP}$ to pregnant female mice on proliferation of thymocytes of the fetuses.

Thymocytes $\left(1.5 \times 10^{6}\right.$ cells $)$ from control or CP treated groups were incubated in vitro at $37^{\circ} \mathrm{C}$ in a humidified atmosphere of $5 \% \mathrm{CO}_{2}$ in air for $72 \mathrm{~h}$. Cell proliferation was checked by MTT assay as described in materials and methods. Values are mean \pm SD of OD at $540 \mathrm{~nm}$ of 3 independent experiments done in triplicate. ${ }^{*} \mathrm{P}$ value $<0.05$ at $95 \%$ confidence interval.
Fig. 7A. Effect of in-vivo administration of $\mathrm{CP}$ to pregnant female mice on $\%$ DNAfragmentation of brain cells of the fetuses. Percent fragmentation of DNA obtained from brain cells of control and CP treated groups was quantified described in materials and methods. Values are mean \pm SD from 3 independent experiments done in triplicate. $* \mathrm{P}$ value $<0.05$ at $95 \%$ confidence interval.

Fig. 7B. Effect of in-vivo administration of $\mathrm{CP}$ to pregnant female mice on proliferation of brain cells of the fetuses. Brain cells $(1.5 \mathrm{x}$ $10^{6}$ cells) from control or $\mathrm{CP}$ treated groups were incubated at $37^{\circ} \mathrm{C}$ in vitro, in a humidified atmosphere of $5 \% \mathrm{CO}_{2}$ in air for $72 \mathrm{~h}$. Cell proliferation was checked by MTT assay as described in materials and methods. Values are mean \pm SD of OD at $540 \mathrm{~nm}$ of 3 independent experiments done in triplicate. ${ }^{*} \mathrm{P}$ value $<0.05$ at $95 \%$ confidence interval. 

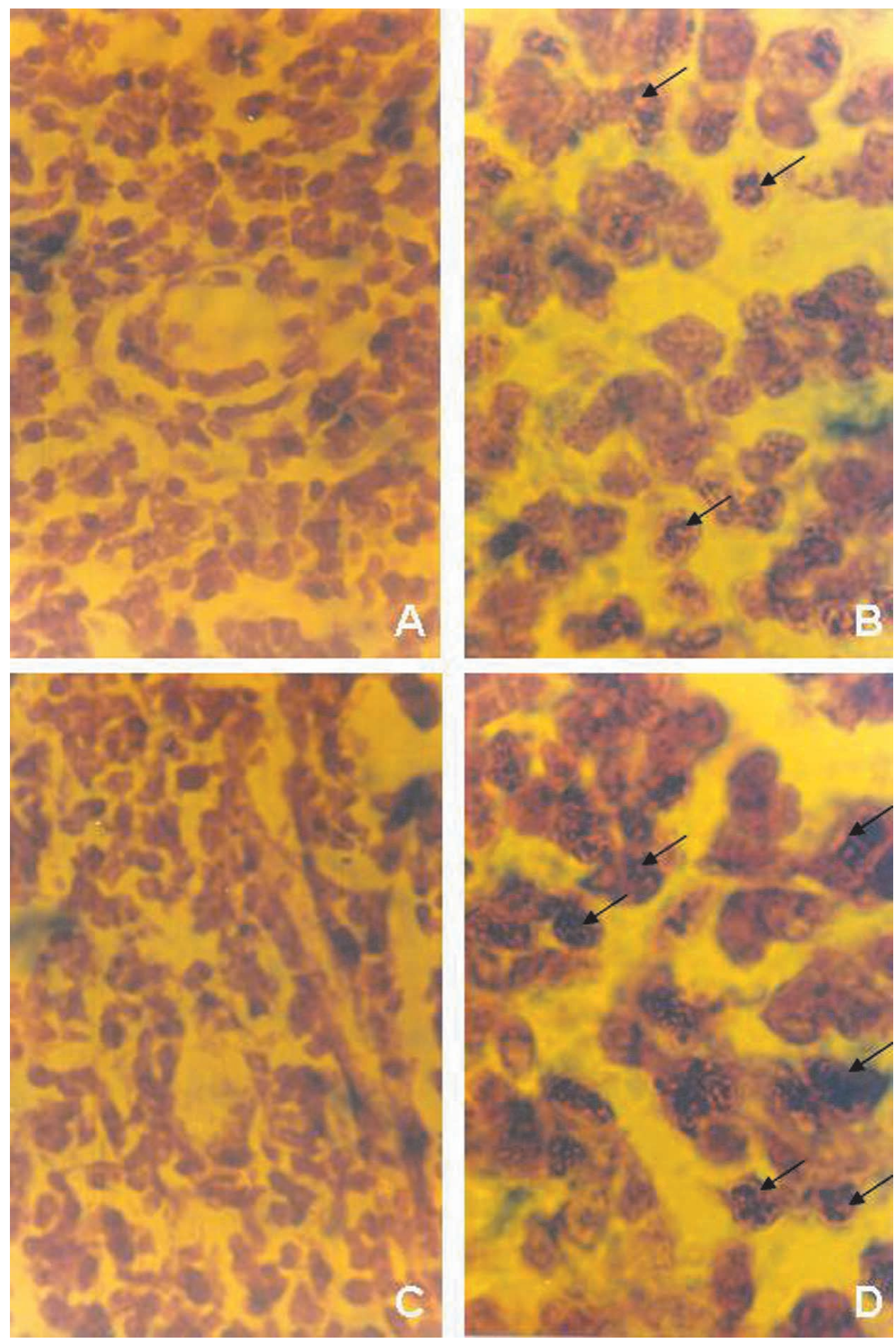

Fig. 8. Photomicrographs of thymuses dissected out from fetuses of control and treated dams collected on day 19 of gestation. A. Histological section of thymus of control fetus at higher magnification showing relatively lightly stained thymocytes and other cells (as compared to treated). Many cells are seen undergoing apoptosis (H\&E x 672). B. Histological section of thymus of control fetus at very high magnification showing number of apoptotic cells which can be identified by morphological features (arrows) H\&E x 1024). C. Histological section of thymus of $\mathrm{CP}$ treated fetus (20 mg on day 11) at higher magnification showing large number of darkly stained apoptotic cells. The proportion of cells undergoing apoptosis was significantly more as compared to controls (A) (H\&E x 672). D. Histological section of thymus of $\mathrm{CP}$ treated fetus $(20 \mathrm{mg}$ on day 11) at very high magnification showing large number of apoptotic cells which can be identified by morphological features (arrows). The incidence of apoptosis was significantly more as compared to controls (B). (H\&E x 1024).

\section{DISCUSSION}

At the time when CP was administered (GD11 mouse) there was neither thymus nor true brain. Any CP effects on immunologic cells occurred at a time when they were only immuno-progenitors expressing 34 antigen with the thymus not yet formed. Furthermore, the "brain" at that time was a series of vesicles a few cell layers thick, containing only progenitor cells and perhaps the trigeminal nerve innervation. How does a teratogenic hit at this time result in 
increased apoptosis over one week later? Following hypothesis is proposed. The use of one single high dose of drug at specific time may have longer lasting teratogenic effect as compared to smaller doses given at short intervals, which might lead to repair of cellular damage and lesions. The biochemical evaluations, which examined both the tissues 8 days after the exposure to CP confirmed profound and persistent changes in the brain and thymus. $\mathrm{CP}$ treatments were associated with the delayed onset apoptosis persistent throughout the time period between drug administration and evaluation of the changes. Hence, more experiments need to be carried out and examined later in follow-up studies keeping in view the selective nature of teratogen induced cell death (Mirkes et al.).

Further, the precise reasons for the observed atrophy of brain are not clear, however, the possibilities can be considered. As CP has been reported to be a well known antimitotic agent it is likely that the loss of brain weight might be contributed to by a gross loss of cell number in the growing fetal brain. The loss in the cellularity in the brain tissue could be attributed to two factors: (1) a decrease in proliferation of brain cells and (2) induction of cell death in the brain cells of $\mathrm{CP}$ treated fetuses. The results of the present study corroborate both the possibilities. Brain cells obtained from $\mathrm{CP}$ treated fetuses upon incubation in vitro showed a decreased proliferative ability (cell number) as compared to brain cells of untreated fetuses. Moreover, the brain cells of fetuses obtained from CP treated mice showed an increased population of cells with typical apoptotic morphology. Therefore, it is suggested that the brain atrophy in fetuses obtained from CP treated mice may not only be due to decreased proliferation of brain cells but also due to the 'switching on' of 'certain preexisting cell death inducing programs. Our interpretations are also supported by reports of other workers who demonstrated that $\mathrm{CP}$ treatment can result in the induction of apoptosis in a variety of immature and mature cell types including neurons (Huang et al., 2002; Linderoth et al., 2003; Mazur-Kolecka et al.; Sharov et al., 2003; Torchinsky et al., 2002; Waxman \& Schwartz, 2003; Wendler, 1981). CPis a broad spectrum alkylating agent and according to Goodman and Gilman's book (Bruton et al., 2006), lethality of DNA alkylation depends on the recognition of the adduct, the creation of DNA strand breaks by repair enzymes, and an intact apoptotic response. Cells thus blocked in the G1-/S interface either repair DNA alkylation or undergo apoptosis (Bruton et al.). Our results of $\%$ apoptotic cell count, \% DNA fragmentation, and cell proliferation assay correlates with the aforementioned mechanisms.

Pillans et al., (1988) reported CP induced reduction in brain weight along with inhibition in the production of the enzyme acetylcholine esterase with $20 \mathrm{mg} / \mathrm{kg}$ body weight when administered on the $10^{\text {th }}$ day after copulation. While our study reports different findings including increase in apoptotic brain cell count and percent DNA fragmentation along with decrease in, in vitro brain cell proliferation assay with either 10 or $20 \mathrm{mg} / \mathrm{kg}$ body weight in a dose dependent manner when administered on 11th day of gestation.

In another study by Pillans et al., (1989), pregnant mice were exposed to teratogenic doses of $\mathrm{CP}$, on the $11^{\text {th }}$ day after copulation and the effects of this agent on embryonal cephalic DNA strand breaks were assessed between 3 and $40 \mathrm{~h}$ after drug administration. Administration of 15,30 and $60 \mathrm{mg} \mathrm{CP} / \mathrm{kg}$ body weight resulted in conversion of 23,30 and $44 \%$ of the DNA to the singlestranded form, respectively. No detectable DNA damage was evident $3 \mathrm{~h}$ after drug administration, but after $6 \mathrm{~h}$ significant DNA damage had occurred, reaching a maximum after $9 \mathrm{~h}$. However, no evidence of DNA strand breaks was present at 22, 30 and $40 \mathrm{~h}$ after $\mathrm{CP}$ treatment, suggesting that these lesions had been repaired. On the contrary in our study CP when administered on 11th day of gestation resulted in dose dependent increase in \% DNA fragmentation of brain cells from 61.25 in control group to 75.71 or 88.81 with 10 or 20 $\mathrm{mg} / \mathrm{kg}$ body weight, respectively, when analyzed and evaluated on $19^{\text {th }}$ day of gestation.

Ogiso et al. (1976) showed that CP caused a considerable decrease in thymic weight along with the total number of thymic lymphocytes and resulted in a significant involution of the thymus. Furthermore, $\mathrm{CP}$ prevented specific proliferation of $\mathrm{T}$ cells along with decreased cytotoxicity of alloantigen-specific $\mathrm{T}$ cell lines by direct induction of apoptosis (Jenkins et al., 1999; Soleman et al., 2003). A number of investigations indicate that lymphocytes treated with $\mathrm{CP}$ result in inhibition of antigen specific proliferation, decreased cytotoxicity, along with an increase in programmed cell death (Jezernik et al,. 2003; Zusman et al., 2002).

Several earlier reports have indicated conflict regarding the effect of $\mathrm{CP}$ on the proliferative and functional ability of T lymphocytes. $\mathrm{CP}$ is a chemotherapeutic agent with a dose-dependent, bimodal effect on the immune system (Lutsiak et al., 2005). While a majority of reports indicate the antimitotic and apoptosis inducing effect of $\mathrm{CP}$ on thymocytes, sporadic observations also indicate that $\mathrm{CP}$ may result in an enhanced $\mathrm{T}$ cell proliferation. There could be several reasons for this discrepancy such as: (1) the age of host treated with $\mathrm{CP}$ may determine the extent of susceptibility of thymocytes to such treatment. While immature $\mathrm{T}$ lymphocytes have been considered to be more prone to exposure of alkylating agents like $\mathrm{CP}$ as compared to the more differentiated and mature lymphocytes; 
thymocytes and splenic T cells of young mice have been reported to be more susceptible to $\mathrm{CP}$ than those of old mice and were decreased in number after the treatment with even a low dose of CP (Barykina et al., 2003; Soleman et al.; Torchinsky et al., 2002). (2) The second reason could be the dose of CP used in the study demonstrating the effects of CP on $\mathrm{T}$ cell proliferation. Lutsiak et al. reported that treatment with low dose (175/kg body weight administered intraperitoneally) of CP inhibits the suppressive capability of Regulatory $\mathrm{T}$ cells manifesting as enhanced immune response. On the contrary as demonstrated by Mochizuki et al. (2003) a single dose of CP $(150 \mathrm{mg} / \mathrm{kg}$ body weight administered intraperitoneally) resulted in suppression of the immune cells along with increase in apoptotic cell count (Mochizuki et al.). The relevance of all the studies to the present work is limited by the fact that they were carried out in adult system and thus the criteria of high dose and low dose is different from that of teratological study. Keeping in view the above mentioned background, in our observation where relatively high doses of CP (10 or $20 \mathrm{mg} / \mathrm{kg}$ body weight) was administered to pregnant mice, finally resulted in a dose dependent massive decline in proliferative ability of thymocytes (cell number) obtained from fetal thymuses of same age.
Farrell et al. (1997) showed that CP administration has a differential effect on the infiltration of leukocyte subtypes and caused abnormal infiltration of immunocompetent lymphocytes in choroids plexus of adult brain and further hypothesized that it may be related to the presence of immunocompetent cells in the brain. Development of such lesions in brain has been attributed to immunological activation of glial cells and lymphocytes in the brain tissue and CP has been demonstrated to contribute to the development of such lesions in brain (Mazur-Kolecka et al.). This could be hypothesized as one of the possible reasons for the observed fetal brain atrophy in our system (although different from our study and carried out in adult brain) as we observed several areas of brain showing development of lesions with massive loss of cells.

Maternal CP treatment on GD 11 in mice results in marked fetal toxicity in form of neurological and immunological embryopathic effects from gross to biochemical levels, characterized by reduced live litter size, fetal body weights as well as brain and thymic weights and malformations which are accompanied by changes in brain protein content, brain and thymic apoptosis, DNA fragmentation and in vitro cell proliferation at term.

PRAKASH; SINGH, G. \& SINGH, S. M. Alteraciones del sistema nervioso central fetal y tímicas posterior al tratamiento con ciclofosfamida en ratas preñadas. Int. J. Morphol., 25(4):775-787, 2007.

RESUMEN: El presente estudio evaluó los cambios en el sistema nervioso e inmunológico en fetos de roedores, luego de exposición a ciclofosfamida $(\mathrm{CF})$ durante la vida intrauterina. Una dosis única de CF de 0,10 , y $20 \mathrm{mg} / \mathrm{kg}$ de peso se administró por medio de inyección intraperitoneal en ratas preñadas (grupo de 20) en el día 11 de gestación (DG11) y luego los fetos se evaluaron en el día 19 de gestación (DG19). Fueron examinados los cambios externos de los fetos, y los cerebros y timos se extrajeron para evaluar los cambios histológicos, contenido de proteínas, conteo de células apoptóticas, fragmentación de DNA y proliferación de células in vitro, usando 1 feto por camada para cada evaluación. Los cerebros y timos de fetos expuestos a CF eran pequeños y completamente deformados, comparado con los del grupo control. La estimación del contenido proteico $(\mathrm{mg} / \mathrm{mL})$ de los cerebros estuvo disminuida en los grupos expuestos a CF. En las células del cerebro y timocitos hubo un incremento en el promedio del conteo de células apoptóticas y el porcentaje promedio de la fragmentación de DNA en los grupos expuestos. Los ensayos de proliferación celular in vitro realizados en células de fetos expuestos, mostraron una disminución en el promedio de células cerebrales y timocitos generados. Estos hallazgos indican que el tratamiento materno en el DG11 con CF en ratones significa una marcada toxicidad fetal caracterizada por un reducido tamaño de los nacidos vivos de la camada, reducidos pesos fetal, cerebral y del timo y malformaciones, las cuales son acompañadas por cambios en el contenido proteico cerebral, apoptosis de células cerebrales y del timo, fragmentación del DNA y proliferación celular in vitro al término.

PALABRAS CLAVE: Ciclofosfamida; Cerebro; Timo; Ratón; Teratología.

\section{REFERENCES}

Aviles. A.; Diaz-Maqueo, J. C.; Talavera, A. et al. Growth and development of children of mothers treated with chemotherapy during pregnancy: current status of 43 children. Am. J. Hematol., 6:243-8, 1991.

Barykina, O. P.; Iuzhakov, V. V.; Chalisova, N. I.; Kvetnoi, I. M. \& Konovalov, S. S. Combined effect of Vilon and Cyclophosphamide on tumor transplants and lymphoid tissue explants in mice and rats of various age. Adv. Gerontol., 12: 128-31, 2003.

Bergstrom, S. K. \& Altman, A. J. Pregnancy during therapy for childhood acute lymphoblastic leukemia: two case reports and a review of the literature. $J$. 
Pediatr. Hematol., Oncol., 20:154-9, 1998.

Brill, A.; Torchinsky, A.; Carp, H. \& Toder, V. The role of apoptosis in normal and abnormal embryonic development. J. Assist. Reprod. Genet., 16:512-9, 1999.

Bruton, L. L.; Lazo, J. S. \& Parker, K.L. Goodman and Gilman's The pharmacological basis of therapeutics. $11^{\text {th }}$ Edition, The MacGraw Hill Companies, Columbus, 2006. pp. 1324-8, 1415.

Bursch, W.; Oberhammer, F. \& Suchulte-Hermann R. Cell death by apoptosis and its protective role against disease. Trends Pharmacol. Sci., 13:245-51, 1992.

Chen. B.; Cyr, D. G. \& Hales, B. F. Role of apoptosis in mediating phosphoramide mustard-induced rat embryo malformations in vitro. Teratology., 50:1-4, 1994.

De Lucia, M. B. I. \& Azoubel, R. Cyclophosphamide Effects on the Epithelial Covering of Rats Fetus's Tongue. A Morphometric Study. Int. J. Morphol., 23:105-9, 2005.

Enns, G. M.; Roeder, E.; Chan, R.T.; Catts, ZA-K.; Cox, V. R. \& Golabi, M. Apparent cyclophosphamide (cytoxan) embryopathy: a distinct phenotype? Am. J. Med. Genet., 86: 237-41, 1999.

Falkson, H. C.; Simson, I. W. \& Falkson, G. NonHodgkins lymphoma in pregnancy. Cancer, 45:167982, 1980.

Farrell, M.; Sakic, B.; Szechtman, H. \& Denburg, J.A. Effect of cyclophosphamide on leukocytic infiltration in the brain of MRL/ipr mice. Lupus, 6:268-74. 1997.

Holladay, S. D.; Sharova, L.V.; Punareewattana, K. et al. Maternal immune response in mice decreases fetal malformations caused by teratogens. Int. Immunopharmacology, 2:325-32, 2002.

Holson, R. R. \& Pierce, B. Principles and pitfalls in the analysis of prenatal treatment effects in the analysis of prenatal treatment effects in multiparous species. Neurotoxicol. Teratol., 14:221-8, 1992.

Huang, C. \& Hales, B. F. Role of caspases in murine limb bud cell death induced by 4-hydroperoxycyclophosphamide, an activated analog of cyclophosphamide. Teratology, 66: 288-99, 2002.
Ivnitsky, I.: Torchinsky, A.; Savion, S.; Shepshclovich, J.; Orenstein, I. I. et al. TGF b2 in embryo with in born anomalies: effect of maternal immunopotentiation. $\mathrm{Am}$. J. Reprod. Immunol., 45:41-51, 2001.

Jenkins, M.; Keir, M. \& Mc Cune, J. M. Fas is expressed early in human in thymocyte development but does not transmit an apoptotic signal. J. Immnol., 163:1195204, 1999.

Jezernik, K. K.; Romih, R.; Mannherz, H. G. \& Koprivec, D. Immunohistochemicel detection of apoptosis, proliferation, and inducible nitric oxide synthase in rat urothelium damaged by cyclophosphamide treatment. Cell Bio. Int., 27:863-9, 2003.

Kirshon, B.; Wasserstrum, N.; Willis, R.; Herman, G. E. \& Mccabe, E. R. B. Teratogenic effects of first trimester cyclophosphamide therapy. Obstet. Gynecol., 72: 462, 1988.

Linderoth, J.; Jerkeman, M.; Cavallin-Stahl, E.; Kvaloy, S. \& Torlakovic, E. Nordic Lymphoma Group Study Immunohistochemical expression of CD23 and CD40 may identify prognostically favourable subgroups of diffuse large B-cell lymphoma: a Nordic Lymphoma Group Study. Clin. Cancer Res., 9: 722-8, 2003.

Lopes, E. R.; Chapadeiro, E.; Raso, P. \& Tafuri, W. L. Wogliolo Patologia. $4^{\text {th }}$ Ed. Rio de Janeiro, Guanabara Koogan, 1987.

Lutsiak, M. E. C.; Semnani, R.T.; De Pascalis, R.; Kashmiri, S. V. S.; Schlom, J. \& Sabzevari, H. Inhibition of $\mathrm{CD} 4+25+\mathrm{T}$ regulatory cell function implicated in enhanced immune response by low-dose cyclophosphamide. Blood, 105: 2862-8, 2005.

Mazur-Kolecka, B.; Grigoriev, V. A.; Kubera, M.; BastaKaim, A. \& Shani, J. Effect of hypothalmic lesion or chemical axotomy on restitution of immunoreactivity in mice after cyclophosphamide administration. Int. J. Immunopharmacol., 18:289-94, 1996.

Mirkes, P. E. \& Little, S. A. Teratogen-induced cell death in post-implantation mouse embryos: differential tissue sensitivity and hallmarks of apoptosis. Cell Death Differ., 5: 592-600, 1998.

Mochizuki, T.; Kuge, Y.; Zhao, S. et al. Detection of apoptotic tumor response in vivo after a single dose of chemotherapy with $99 \mathrm{~m} \mathrm{Tc}$-annexin V. J. Nucl. Med., 45:526, 2003. 
Ogiso, T.; Noda, N., Asai, N. \& Kato, Y. Antitumor agents. I. Effect of 5-fluorouracil and cyclophosphamide on liver microsomes and thymus of rat. Jpn. J. Pharmacol., 26:445-53, 1976.

Pillans, P. I.; Ponzi, S. F. \& Parker, M. I. Cyclophosphamide induced DNA strand breaks in mouse embryo cephalic tissue in vivo. Carcinogenesis, 10: 83-5, 1989.

Pillans, P. I.; Stephenson, B. A. \& Folb, P. I. Cyclophosphamide effects on fetal mouse cephalic acetylcholinesterase. Arch. Toxicol., 62:230-1, 1988.

Pizzuto, J.; Aviles, A.; Noriega, L.; Niz, J.; Morales, M. \& Romero, F. Treatment of acute leukemia during pregnancy: presentation of nine cases. Cancer Treat Rep., 64:679-83, 1980.

Reddy, S.; Bradley, J.; Ginn, S.; Pathipati, P. \& Ross, J. M. Immunohistochemical study of caspase-3-expressing cells within the pancreas of non-obese diatetic mice during cyclophosphamide-accelerated diabetes. Histochem. Cell. Biol., 119:451-61, 2003.

Savion, S.; Kamshitsky-Feildman, A.; Ivnitsky, I. et al. Potentiation of the maternal immune system may modify the apoptotic process in embryos exposed to developmental toxicants. Am. J. Reprod. Immunol., 49:30-41, 2003.

Sellins, K.S., Cohen, J.J. Gene induction by gammairradiation leads to DNA fragmentation in lymphocytes. J. Immunol., 139:3199-206, 1987.

Sharov, A. A.; Li, G. Z.; Palkina, T. N.; Sharova, T.Y.; Gilchrest, B. A. \& Botchkarev, V. A. Fas and C-lit are involved in the control of hair follicle melanocyte apoptosis and migration in chemotherapy-induced hair loss. J. Invest. Dermatol., 120:27-35, 2003.

Singh, N.; Singh, S. M. \& Shrivastava, P. Immunomodulatory effect of Tinospora cordifolia in tumor-bearing host. Oriental Pharmacy and Experimental Medicine., 3:72-9, 2003.

Singh, S.; Dutta, A. N. \& Singh, G. Retarded recovery of purkinje cells in rats following cyclophosphamide treatment in early postnatal period. Indian J. Exp. Biol., 21:539-45, 1983.

Singh, S. N.; Mohanty, S. \& Singh, G. Hydrocephalus indubycyclophosphamide in chick embryos. Neurosurgery, 27: 103-5, 1990.
Soleman, D.; Cornel, L.; Little, S. A. \& Mirkes, P. E. Teratogen-induced activation of the mitochondrial apoptotic pathway in the yolk sac of day 9 mouse embryos. Birth Defects Res. Part A Clin. Mal. Mol. Teratol., 67:98-107, 2003.

Strauss, G.; Osen, W. \& Debatin, K. M. Induction of apoptosis and modulation of activation and effector function in T cells by immunosuppressive drugs. Clin. Exp. Immunol., 128:255-66, 2002.

Torchinsky, A.; Ivnitskty, I.; Savion, S.; Shepshelovich, J.; Gorivodsky, M. \& Toder, V. Cellular events and pattern of p53 protein expression following cyclophosphamide-initiated cell death in various organs of developing embryo. Teratog. Carcinog. Mutagen., 19:353-67, 1999

Torchinsky, A.; Lishanski, L.; Wolstein, O. et al. NF-kappa B DNA-binding activity in embryos responding to a teratogen cyclophosphamide. BMC Dev. Biol., 2:2, 2002.

Waxman, D. J. \& Schwartz, P. S. Harnessing apoptosis for improved anticancer gene therapy. Cancer Res., 63:8563-72, 2003

Wendler, D. Teratogenic damage of the central nervous system during progressing embryogenesis. Gegenbaurs Morphol Jahrb., 127:641-8, 1981.

Zemlickis D.; Lishner, M. \& Erlich, R. Teratogenicity and carcinogenicity in a twin exposed in utero to cyclophosphamide. Teratog. Carcinog. Mutagen, 13:139-43, 1993.

Zusman, I.; Kossoy, G. \& Ben-Hur, H. T cell kinetics and apoptosis in immune organs and mammary tumors of rats treated with cyclophosphamide and soluble tumorassociated antigens. In Vivo, 16: 567-76, 2002.

Corresponce to:

Dr. Prakash

Assistant Professor

Department of Anatomy

CBS, Bejai,

Kasturba Medical College

Pin code: 575004

Mangalore

Karnataka, India

Email: prakashrinku@rediffmail.com

Received: 08-02-2007

Accepted: 14-05-2007 
